\title{
Effects of Ambient Oxygen and Density on Primary Soot Size under Diesel-Like Conditions Using a Lagrangian Soot Tracking Model
}

Ong, Jiun Cai; Pang, Kar Mun; Walther, Jens Honore; Ho, Jee-Hou; Ng, Hoon Kiat

Published in:

S A E International Journal of Engines

Link to article, DOI:

10.4271/03-14-02-0018

Publication date:

2021

Document Version

Peer reviewed version

Link back to DTU Orbit

Citation (APA):

Ong, J. C., Pang, K. M., Walther, J. H., Ho, J-H., \& Ng, H. K. (2021). Effects of Ambient Oxygen and Density on Primary Soot Size under Diesel-Like Conditions Using a Lagrangian Soot Tracking Model. S A E International Journal of Engines, 14(2), 301-315. https://doi.org/10.4271/03-14-02-0018

\section{General rights}

Copyright and moral rights for the publications made accessible in the public portal are retained by the authors and/or other copyright owners and it is a condition of accessing publications that users recognise and abide by the legal requirements associated with these rights.

- Users may download and print one copy of any publication from the public portal for the purpose of private study or research.

- You may not further distribute the material or use it for any profit-making activity or commercial gain

- You may freely distribute the URL identifying the publication in the public portal 
1 Effects of Ambient Oxygen and Density on Primary Soot Size under Diesel-

2 like Conditions using a Lagrangian Soot Tracking Model

3 Abstract

4 This paper investigates the effect of ambient oxygen levels and ambient density on the

5 primary soot size under diesel engine-like conditions via a Lagrangian soot tracking (LST)

6 method. The numerical studies and soot analysis are carried out for an $n$-heptane spray flame

7 in the Sandia constant volume combustion chamber. Numerical studies are carried out at two

8 oxygen levels of $15 \%$ and $12 \%$, as well as two ambient densities of $14.8 \mathrm{~kg} / \mathrm{m}^{3}$ and $30 \mathrm{~kg} / \mathrm{m}^{3}$.

9 The LST model involves treating the soot particles formed in the spray flame as Lagrangian

10 particles and their individual soot information are stored. Based on the primary soot size

11 distribution for soot particles in the core of the spray jet, an increase in ambient density from

$1214.8 \mathrm{~kg} / \mathrm{m}^{3}$ to $30 \mathrm{~kg} / \mathrm{m}^{3}$ is shown to increase the peak and mean soot size by a factor of 1.5 .

13 Furthermore, the peak and mean primary soot size decreases with decreasing oxygen levels

14 from $15 \%$ to $12 \%$. The larger primary soot at higher oxygen levels and ambient densities can

15 be attributed to the higher net growth rate experienced by the soot particles. At low density,

16 the span of soot cloud is shorter at low oxygen level. In contrast, the high density cases show

17 comparable soot cloud span for both oxygen levels before steady-state is reached. Soot age is

18 introduced to predict the soot residence time in the spray flame. The results show that soot

19 residence time is dependent on both the span of the soot cloud and the initial onset location of

20 the soot formed.

21 Keywords: Lagrangian soot tracking; primary soot; soot age; soot size; diesel spray 


\section{Introduction}

23 Soot is one of the most distinctive and problematic emissions of diesel engines due to its complex formation and oxidation processes. Soot particles are normally formed as fractal open structured agglomerates with large quantities of nano-sized primary particles via incomplete combustion of hydrocarbon fuels [1,2]. The morphological characteristics and nanostructural properties of combustion-generated soot particles are of paramount importance because they are closely linked to the formation of primary soot particles and soot oxidative reactivity [3]. Furthermore, ultrafine particle emissions from incomplete combustion are harmful to human health [4,5]. This concern has led to the legislation of Euro 5/6 which aims to reduce soot mass and particle number emissions [6,7]. Driven by the stringent legislations for pollutant emissions, detailed analysis of soot morphology and its evolution could provide useful insights into mitigating the detrimental impact of particle emissions.

from a diesel spray flame has emerged to be a powerful and quantitative technique for studying soot particle size. This direct soot sampling technique has been successfully applied in reacting diesel jets, under high-pressure and high-temperature ambient conditions for soot study in a constant volume vessel [8-14], as well as in diesel engines [15-17]. Kook and Pickett [8] studied the morphology of soot particles extracted from diesel spray flames at ambient temperature and density of $1000 \mathrm{~K}$ and $6.7 \mathrm{MPa}$, respectively in a constant volume vessel by using a thermophoretic probe. The TEM analysis of the soot samples along different in-flame axial locations revealed that the diameters of primary soot increase at first, reach a peak and then decrease [8], in which the decrease in primary soot size is due to soot oxidation. Several studies $[9,18]$ showed similar trend. Similar sampling technique and TEM analysis were used by Kuribayashi et al. [14] to study the effects of oxygen $\left(\mathrm{O}_{2}\right)$ level $(15 \%$ and $21 \%$ ) on soot concentration, size, number density and morphology in a diesel spray 
flame. They found that lowering the ambient oxygen concentration resulted in a delayed and downstream-shifted soot processes, as well as an increase in the aggregate size in the downstream region. However, the primary soot size remained relatively stable when the oxygen concentration decreased from $21 \%$ to $15 \%$. Besides this work, the same approach (direct sampling and TEM analysis) has also been applied in other studies, such as fuel comparison among conventional diesel, biodiesel and Fischer-Tropsch Diesel [11,12], effect of injected fuel amount [17], and nanostructure analysis of primary particles [19,20]. Despite successful implementation in various studies, a major limitation of the direct soot sampling and TEM analysis is the time resolution. Since the thermophoretic probe is constantly exposed to the diesel flame, the sampled soot is a time-integrated mixture of soot particles throughout the injection and combustion duration. Therefore, the use of computational fluid dynamics (CFD) is expected to overcome the limitations of TEM analysis of sampled soot by giving instantaneous spatial or temporal information of the soot formation process.

There are a few methods available for CFD analysis that can model soot size distribution. One approach is the Method of Moments (MOM) [21], in which the evolution equations for moments of the population distribution are solved instead of explicitly solving the population distribution [22]. MOM was used by Ito et al. [23] who compared the predicted primary soot size from MOM against the measurement data from a laser-induced incandescence experiment of $n$-heptane spray combustion in a constant volume chamber. Recently, Naik et al. [24] utilized MOM in their simulation study of high-pressure lifted flames in a constant-volume chamber. In addition to $n$-heptane fuel, a two-component surrogate fuel, conventional U.S. No. 2 diesel (D2), and world-averaged jet fuel (Jet-A) were considered in their simulation study [24]. Another approach is the discrete sectional method (DSM) [25-27] which discretizes the population of soot particles into discrete sections or "bins" and the evolution equations are solved for each of these bins. This method has been 
applied to model primary soot size distribution in optical engine [28,29]. It is important to note that MOM only predicts ensemble averaged quantities where the exact shape of the particle size distribution is unknown. As for DSM, in order to achieve good accuracy, a higher number of sections is needed to represent the particle size distribution, thus making it computationally expensive. It is also noteworthy that both MOM and DSM can only provide the mean primary particle soot size, and do not provide information about the history of the soot particles which may contain vital information to understand the soot processes.

The Lagrangian tracking method is an alternative to DSM and MOM for computing particle dynamics. It allows the possibility to track an individual particle continuously along its trajectory, and to monitor its individual interaction with both the gas phase and the other particles. No classes or sections of particles are required, thus making the calculation of the particle size distribution relatively straightforward. Gallen et al. [30] introduced a semideterministic Lagrangian particle tracking methodology that tracks the Lagrangian soot particles as well as consider their collision process. A hybrid Eulerian-Lagrangian method for soot modelling, which was developed by Dellinger et al. [31], combined a reduced gas-phase chemistry, a sectional model for polycyclic aromatic hydrocarbons, and a Lagrangian description of soot particles dynamics. The Lagrangian soot particles were nucleated from polycyclic aromatic hydrocarbons molecules and radicals. Meanwhile, two-way coupling of the gaseous and solid phases was assumed. It is important to note that the aforementioned studies were both related to gas turbine applications. A Lagrangian soot tracking (LST) model based on a semi-empirical formulation was recently developed by Ong et al. [32] and was successfully implemented for diesel spray applications. The LST model was validated using the experimental data of $n$-dodecane and $n$-heptane spray flame from the Engine Combustion Network. Despite omitting the coagulation process, the LST model was 
demonstrated to be able to predict primary soot size, track individual soot particles, and access their history as they evolve in the diesel spray flame.

Setting against this background, the present study is carried out by integrating the previously developed LST model [32] with a reduced $n$-heptane chemical mechanism to investigate the effect of ambient oxygen and density on primary soot size in a Sandia $n$ heptane reacting spray. The paper is structured such that numerical formulation and setup are first provided. This is followed by the validation of CFD models using non-reacting and reacting spray experimental data. The validation of the LST method is carried out by comparing the distribution of the steady-state soot volume fraction (SVF). Following this is the study of soot size distribution for soot particles formed at the core of the jet during the transient and the steady-state phase.

\section{Numerical formulation and setup}

\subsection{Mesh and numerical models}

The computational study was performed using the spray combustion solver in an open-source code, OpenFOAM version 2.0.x [33]. Experimental data from the Sandia combustion vessel [34] was used for the model validation of the $n$-heptane spray and its combustion characteristics. Detailed descriptions of the experimental setup are available in [34]. The constant volume combustion vessels were represented by a cylinder during simulation studies. For computational expediency, the cylindrical chamber was simplified to a 4-degree axisymmetric wedge with a single layer of cells in the tangential direction. Details of the mesh and geometry can be found herein [32]. The time step size was fixed at $0.2 \mu \mathrm{s}$. The nonreacting spray case was studied at an ambient temperature of $1000 \mathrm{~K}$ and ambient density of $14.8 \mathrm{~kg} / \mathrm{m}^{3}$ with the absence of oxygen $\left(0 \% \mathrm{O}_{2}\right.$ in ambient gas composition). As for the reacting spray case, there were a total of four cases with two oxygen concentrations $(15 \%$ and 
$12012 \%$ ) and two ambient densities $\left(14.8 \mathrm{~kg} / \mathrm{m}^{3}\right.$ and $\left.30 \mathrm{~kg} / \mathrm{m}^{3}\right)$, while having the same initial ambient temperature of $1000 \mathrm{~K}$. Cases with ambient density of $14.8 \mathrm{~kg} / \mathrm{m}^{3}$ and $30 \mathrm{~kg} / \mathrm{m}^{3}$ were henceforth addressed as low density and high density cases, respectively for brevity. Injection specifications and profiles in the current simulations were set to correspond to those used in the experimental setup. Details of the experimental conditions and the injection parameters are shown in Table 1.

The spray breakup was described using the Reitz-Diwakar model [35]. The model constant that governs the time factor for stripping, $C_{S}$ was set to 11.5. The turbulent flow was modelled using the Unsteady Reynolds Averaged Navier-Stokes (URANS) method with the standard $k-\varepsilon$ model [36]. The model constant $C_{1 \varepsilon}$ was calibrated according to its approximation of round jets $[37,38]$ and set to a value of 1.53 . The initial turbulence kinetic energy, $k$ was set to $0.735 \mathrm{~m}^{2} / \mathrm{s}^{2}$, which was estimated based on the measured RMS velocity in the experiment [34]. The initial turbulence dissipation rate, $\varepsilon$ was set to $5.67 \mathrm{~m}^{2} / \mathrm{s}^{3}$ based on the turbulence integral length scale of $0.01 \mathrm{~mm}$. The choice of the initial $k$ and $\varepsilon$ are similarly used in Ref. $[38,39,40]$. The average velocity in the combustion chamber prior to spray injection is approximately $0.7 \mathrm{~m} / \mathrm{s}$ as provided in ECN [34]. This gas velocity is too low to cause significant effect on the spray development as the spray velocity is $400-600$ $\mathrm{m} / \mathrm{s}$. Therefore, the initial velocity field for all cases was set to be zero. Similar treatment of

138 the initial velocity field can be seen in Ref. [39]. Soot radiation modelling was neglected in

139 all test cases [41]. Collision and coalescence with the fuel spray region were omitted in all 140 studies as these processes have negligible influence on the liquid and vapour fuel penetration 141 of evaporating spray [42]. In addition, the Ranz-Marshall correlation [43] was implemented 142 to calculate the droplet heat transfer with the surrounding gas phase while the Frossling 143 correlation [44] was used to model the evaporation of droplet fuel. The skeletal $n$-heptane 144 mechanism developed by Pang et al. [45] was implemented to describe the chemical kinetics 
145 of $n$-heptane spray combustion. Details about the mechanism can be referred to in [45]. In

146 this current study, the spray combustion solver was incorporated with a LST model [32]. The

147 LST model is explained in detail in our previous study [32] but for completeness the essential

148 features are outlined here.

\section{$149 \quad 2.2$ LST model for soot particles}

150 The LST model treats soot particles as Lagrangian particles and they are tracked via the

151 Lagrangian method, in which the motion of the soot particles are computed using Newton's second law of motion. The dispersion of Lagrangian particles due to turbulence is influenced

153 by the instantaneous fluctuating velocity $\overrightarrow{u^{\prime}}[46,47]$, which is modelled by the discrete random walk model (DRW) [46, 47]. It correlates with the flow turbulent kinetic energy $k$,

155 predicted by the standard $k-\varepsilon$ model, and is expressed by

$$
\overrightarrow{u^{\prime}}=\zeta \sqrt{2 k / 3}\left\{\begin{array}{l}
1 \\
1 \\
1
\end{array}\right\}
$$

156 where $\zeta$ is a Gaussian random number $[45,46]$ with zero mean and unit variance.

157 The LST model also considers the inception, surface growth and oxidation processes

158 of the soot particles. It is important to note that the coagulation process is omitted in the LST

159 model as the surface growth is the relatively dominant process in affecting primary soot

160 particle size $[48,49]$. The inception, surface growth and oxidation rates in the LST model are

161 adapted from the semi-empirical, multi-step Moss-Brookes (MB) soot model [50]. The MB

162 soot model is chosen due to its flexibility in implementing different surface ageing model, as

163 shown in Ref. [51].

164 The inception rate, $\omega_{\text {inc }}$ is given by

$$
\omega_{\text {inc }}=C_{\text {inc }} M_{P}\left(\frac{X_{\text {prec }} P}{R T}\right) \exp \left\{-\frac{T_{i n c}}{T}\right\}
$$


where $X_{\text {prec }}$ denotes the mole fraction of soot precursor, whereas $C_{i n c}$ is the model constant

166 for soot incipient rate and is given as $54 \mathrm{~s}^{-1} . T, P$ and $R$ denote the gas temperature, pressure

167 and universal gas constant, respectively. The activation temperature of soot inception, $T_{i n c}$ is given as $21,000 \mathrm{~K}$. The constant $M_{P}$ represents the mass of an incipient soot particle which is set to $1200 \mathrm{~kg} / \mathrm{kmol}$. In the LST model, Lagrangian particles are formed when a formation criterion in a computational cell is met. The formation criterion at cell $j$ is given as

$$
m_{i n c, j}>m_{i n c, \min }
$$

where $m_{i n c, j}$ denotes the total incipient soot mass at cell $j$ and $m_{i n c, \min }$ denotes the minimum mass of incipient soot. $m_{i n c, j}$ is calculated by taking the product of $\omega_{i n c, j}$ and the time-step

$173 \Delta t$. Meanwhile, $m_{i n c, \min }$ is calculated to be $2.0 \times 10^{-24} \mathrm{~kg}$, based on the assumption that the 174 minimum diameter of an incipient soot is $1.24 \mathrm{~nm}$ [52], with the soot density of $2000 \mathrm{~kg} / \mathrm{m}^{3}$ $175[52,53]$. The single formed Lagrangian particle is assumed to represent the total number of 176 incipient soot particles in that particular computational cell at that time instance. It is also assumed that all particles formed in that cell, at that instant, follow the same pathway [54] and size change as the existing Lagrangian particle. The initial velocity of the new particle formed follows the mean velocity of the cell it is formed in. The newly formed Lagrangian particles then undergo mass addition and increase in

181 size through the surface growth process and decrease in size due to oxidation processes via 182 hydroxyl radicals $(\mathrm{OH})$ and $\mathrm{O}_{2}$. The rate of change of soot diameter due to surface growth is governed by Equation (4), whereas the diameter change due to oxidation is by Equation (5) 184 and (6).

$$
\left.\frac{d}{d t}\left(d_{i}\right)\right|_{S G}=\alpha\left[2 C_{s g}\left(\frac{X_{s g} P}{R T}\right) \frac{1}{\rho_{\text {soot }}} \exp \left\{-\frac{T_{\gamma}}{T}\right\}\right]
$$




$$
\begin{gathered}
\left.\frac{d}{d t}\left(d_{i}\right)\right|_{\text {ox via } \text { OH }}=2 C_{O H} \eta_{\text {coll }}\left(\frac{X_{O H} P}{R T}\right) \frac{\sqrt{T}}{\rho_{\text {soot }}} \\
\left.\frac{d}{d t}\left(d_{i}\right)\right|_{\text {ox via } O_{2}}=2 C_{O_{2}}\left(\frac{X_{O_{2}} P}{R T}\right) \frac{\sqrt{T}}{\rho_{\text {soot }}} \exp \left\{-\frac{T_{O_{2}}}{T}\right\}
\end{gathered}
$$
soot oxidants, $\mathrm{OH}$ and $\mathrm{O}_{2}$ are represented by $X_{O H}$ and $X_{O_{2}}$, respectively. It is important to

187 note that acetylene $\left(\mathrm{C}_{2} \mathrm{H}_{2}\right)$ is chosen here as the surface growth species and soot precursor

188 species. Although polycylic aromatic hydrocarbon is also an important soot precursor. To 189 accurately predict the formation of PAH, a larger chemical mechanism that includes PAH 190 formation pathways is required, which will incur higher computational cost. Furthermore, 191 numerous numerical studies of soot formation in diesel spray flame consider only acetylene 192 as soot precursor, e.g. Ref. [38, 55-57]. Therefore, only acetylene is chosen as the soot 193 precursor to achieve a balance of accuracy and computational efficiency. Furthermore, one-

194 way coupling is assumed between the Lagrangian soot particles and the gaseous species. This implies that the gaseous species affects the Lagrangian soot particles but not the other way around. The soot model constants, their descriptions and values are shown in Table 2. The $\alpha$

197 in Equation (4) denotes the surface ageing factor, which is assumed to be a function of

198 temperature and is expressed as

$$
\alpha=\frac{1}{2}\left(\tanh \left(\frac{8168}{T}-4.57\right)+1\right)
$$

199 Once a Lagrangian soot particle is reduced below a threshold diameter, it is assumed to be

200 fully oxidised and is removed from the computational cell. The threshold value is set to 1.24 $\mathrm{nm}$ which is the same as the initial incipient soot particle size. 


\section{Results and discussion}

\section{$203 \quad 3.1$ Validation of numerical models}

204 The first part of this section compares the simulation results of non-reacting fuel spray against experimental measurements, in terms of liquid and vapour penetration lengths as well as the mixture fraction. It is followed by the validation of the computed ignition delay times (IDT) and lift-off lengths (LOL) of reacting sprays using the experimental data [34]. The non-reacting and reacting spray validation cases are carried out to ensure that the fuel-air distribution and combustion characteristics are reasonably simulated, and the uncertainties induced by these elements can be minimised prior to studying soot formation events. The

211 validation of LST model is carried out by comparing the predicted SVF profiles with

212 measured data during steady-state combustion for different ambient conditions.

In the current work, the liquid penetration length (LPL) is taken as the axial location

214 from the injector to the location where $99 \%$ of the total liquid mass is found, while the vapour 215 penetration length (VPL) is taken as the maximum distance from the nozzle outlet to where 216 the fuel mass fraction (or mixture fraction) is $0.1 \%$. As for the LOL, it is defined as the first 217 axial location of Favre-averaged $\mathrm{OH}$ mass fraction which reaches $2 \%$ of its maximum value 218 in the domain. The time averaging of the simulated LOL is carried out from 3.0 to $6.0 \mathrm{~ms}$.

219 This corresponds to the experimental definition. The IDT is defined as the time when the

220 greatest rise of maximum temperature is observed, $\left(\frac{d T_{\max }}{d t}\right)_{\max }$, and this definition remains 221 consistent throughout the study. Although there are other definitions for the IDT, it is shown 222 that there is no significant discrepancy in the IDT between different IDT definitions [39].

223 Moreover, this definition is in accordance with the recommendation by the Engine 224 Combustion Network [34]. 


\subsubsection{Non-reacting spray simulations}

226 Comparisons between the computed and measured penetration lengths are provided in Figure

227 1(a) using the default and calibrated model constant. In general, the tuned model shows an

228 improved VPL and LPL prediction as compared to the measurement. Computed and

229 measured mean radial mixture fraction profiles are next compared in Figure 1(b). The overall

230 trend of the mixture fraction profiles agrees with the experimental data which implies that the

231 air-fuel distributions are reasonably predicted by the model.

\section{$232 \quad 3.1 .2$ Reacting spray simulations}

233 Figure 2 shows the comparison of experimental and predicted IDT/LOL for the reacting $n$ -

234 heptane spray cases at different oxygen levels and ambient densities. At low density, the predicted IDTs correspond well with the measured IDT for $15 \%$ and $12 \%$ oxygen levels with a maximum relative difference of $7.3 \%$. A maximum relative difference of $17.5 \%$ is obtained for the predicted IDT at a higher ambient density of $30.0 \mathrm{~kg} / \mathrm{m}^{3}$. At high density $\left(30.0 \mathrm{~kg} / \mathrm{m}^{3}\right)$, the predicted LOLs at both oxygen levels are within a relative difference of $7 \%$ as compared to the experimental LOL. At low density $\left(14.8 \mathrm{~kg} / \mathrm{m}^{3}\right)$, the predicted LOL at $12 \% \mathrm{O}_{2}$ and $15 \% \mathrm{O}_{2}$ are underpredicted by $6 \%$ and $20 \%$, respectively. Nevertheless, the simulated LOLs

241 are shown to correspond well with the measured data for all the reacting spray cases by

242 capturing the LOL trend, where the LOL increases with increasing ambient density and

243 decreasing oxygen levels.

\subsubsection{Steady-state SVF distribution}

245 In this section, the predicted SVF results using the LST model are compared against the

246 measured SVF for different oxygen concentrations and ambient densities. The experimental

247 SVF are obtained from the time-averaged line-of-sight extinction (KL) data [34]. Predicted

248 SVF using the LST model is calculated based on the total number of Lagrangian soot

249 particles in the domain. Figure 3 shows the temporal evolution of the number of 
computational particles for soot under different ambient densities and oxygen levels. It is depicted in the figure that the number of soot particles reaches a quasi-steady state at $t \geq 4$ ms. Therefore, the predicted steady-state SVF using the LST model is obtained by timeaveraging the computed SVF from $4-6 \mathrm{~ms}$. In addition, normalization is carried out by normalizing the simulated and measured SVF with their respective peak SVF at $15 \% \mathrm{O}_{2}, 30.0$ $\mathrm{kg} / \mathrm{m}^{3}$ density. The normalized SVF profiles for different oxygen levels and ambient densities along the spray axis are shown in Figure 4. The simulated SVF for the $12 \% \mathrm{O}_{2}, 30.0 \mathrm{~kg} / \mathrm{m}^{3}$ density case is underpredicted by approximately $30 \%$ relative to the measured data. At low density, the predicted SVF at $15 \% \mathrm{O}_{2}$ is overpredicted by a factor of two as compared to the measured result. The larger discrepancy at $15 \% \mathrm{O}_{2}$ is likely due to the underpredicted LOL which leads to less air entrainment into the spray and subsequently higher soot formation (cf. Figure 2). Despite these discrepancies, the predicted SVF using the LST model is shown to increase with increasing oxygen level and ambient density, which corresponds with the experimental observation as depicted in Figure 4. The spatial location of the predicted SVF is

264 further downstream than the measured SVF. This can be attributed to the use of the Moss-

265 Brookes soot model in the formulation of the LST model which is discussed in [32]. It is shown in Ref. [39] that considering surface ageing effect in the surface growth model can cause the spatial location of the soot cloud to be more upstream. Therefore, it is expected that implementing a more advanced surface ageing model than the one implemented in the present study will likely improve the spatial prediction of the LST model. Despite the overprediction, the LST model is able to capture the variation of spatial location of SVF towards the upstream location of the spray as oxygen level increases and ambient density increases, which coincides with experimental observation (cf. Figure 4). It is important to note that a single simulation case using the LST model requires approximately 170 hours to 
reach $6.0 \mathrm{~ms}$ after start of fuel injection when running in serial on a HP Z200 Workstation with Quad-Core Intel Xeon Processor 3400 at $2.40 \mathrm{GHz}$.

\subsection{In the spray core jet}

\subsubsection{Sampling of individual lagrangian soot particless}

The soot sampling experiment was conducted by Aizawa and colleagues, in which full details of the experimental methodology can be seen in Ref. [11-13]. For completeness of the present paper, only the essential steps are highlighted here. The soot sampling experiment involves placing a probe in-parallel to the spray axis to skim the gas containing soot from the spray flame while minimizing the flow disturbance to the other half of the spray flame. As the reacting flow passes the probe, soot particles are deposited onto the carbon-coated copper grid inside the probe via thermophoresis. The sampled soot particles correspond to the soot present at that position. Sampled soot particles at different locations along the spray axis can be obtained by repeating the experiment with the probe being at different locations along the spray axis. The sampled soot particles are then observed under a High-Resolution Transmission Electron Microscope (HR-TEM). The diameter of each primary soot particles is finally obtained by manually processing the TEM images.

In order to simulate the same sampling technique along the spray axis, Lagrangian particles which are $\pm 1.5 \mathrm{~mm}$ axially and $\pm 0.5 \mathrm{~mm}$ radially about the sampling locations are assumed to be deposited onto the sampler and thus, their information is recorded. Similar analysis was carried out in our previous work [32]. Information of the deposited Lagrangian particles, such as size, position, velocity, etc, are gathered from the start of ignition (SOI) to $6.0 \mathrm{~ms}$ after start of ignition (ASOI). The analysis of the information gathered on the individual Lagrangian particles is later carried out in subsequent sections to obtain the primary soot size distribution and study its relation to soot processes. 
299 The effect of ambient oxygen and density on primary soot size distribution at the core of the 300 spray jet for the $n$-heptane spray cases are investigated here. The probability density function 301 (PDF) of primary soot size for various ambient oxygen level and density cases are shown in

302 Figure 5. It is observed that the onset location of soot moves downstream as oxygen level

303 decreases. Soot is present at $x=50 \mathrm{~mm}$ for the $15 \% \mathrm{O}_{2}$, low density case, while soot is only

304 present further downstream at $x=60 \mathrm{~mm}$ for the $12 \% \mathrm{O}_{2}$, low density case. This

305 phenomenon is similarly captured for the high density case (not shown in the figure). The

306 variation of soot onset location with oxygen level coincides with the experimental

307 observation in [58-60] and in Section 3.1.3. Furthermore, Figure 5 also shows that in all the

308 cases the primary soot diameters increase as soot particles migrate downstream. This is

309 caused by the soot undergoing surface growth process and is consistent with experimental

310 observations $[8,9,18]$

The mean primary soot diameter is computed from the collected Lagrangian particles

312 along the core of the spray jet from the SOI to $6.0 \mathrm{~ms}$ ASOI and is shown in Figure 6. The mean primary soot size predicted at the oxygen level of $15 \%$ and ambient density of $30 \mathrm{~kg} / \mathrm{m}^{3}$

314 is in reasonable agreement with the measured mean primary soot size using $n$-dodecane fuel

315 [61]. For the low density case, the mean primary soot size reaches a peak value of

316 approximately $4.5 \mathrm{~nm}$ and $3.2 \mathrm{~nm}$ for oxygen levels of $15 \%$ and $12 \%$, respectively. As

317 ambient density increases to $30.0 \mathrm{~kg} / \mathrm{m}^{3}$, the peak value of the predicted mean primary soot

318 size also increases to $6.2 \mathrm{~nm}$ and $4.5 \mathrm{~nm}$ for oxygen levels of $15 \%$ and $12 \%$, respectively.

319 This implies that the increase in density resulted in the primary soot size to increase by a

320 factor of 1.5. Furthermore, it is also evidently shown in Figure 6 that the mean primary soot

321 size decreases with decreasing oxygen levels. There have been no experimental studies on the effects of ambient oxygen and density on primary soot size in diesel spray flame for $n$ - 
heptane fuel. However, experimental studies on SVF have shown that decreasing ambient oxygen [58] and increasing ambient density [62] can increase SVF in diesel spray flame. In addition, measurement of primary soot size in canonical flame setups also showed similar findings regarding the effect of oxygen [63] and ambient density [64-66] on primary soot 327 sizes.

The results presented in Figures 5 and 6 are time-integrated results of all the collected Lagrangian particles along the core of the spray jet from the SOI to $6.0 \mathrm{~ms}$ ASOI. In order to gain a better insight on the effect of ambient oxygen and density on the primary soot size, the instantaneous primary soot size and the corresponding net growth rates experienced by the soot particles are analysed next. The temporal evolution of the net growth rates for all the cases are presented in Figure 7. Moreover, their corresponding evolution of the primary soot size distribution with respect to axial distance is presented in Figure 8.

At low density $\left(14.8 \mathrm{~kg} / \mathrm{m}^{3}\right)$, the maximum net growth rates for the $15 \% \mathrm{O}_{2}$ and $12 \%$ $\mathrm{O}_{2}$ cases are $1 \times 10^{5} \mathrm{~kg} / \mathrm{m}^{3} / \mathrm{s}$ and $0.25 \times 10^{5} \mathrm{~kg} / \mathrm{m}^{3} / \mathrm{s}$, respectively. The span of soot cloud for the $12 \% \mathrm{O}_{2}$ case is shorter than the $15 \% \mathrm{O}_{2}$ case from $1.0 \mathrm{~ms}$ ASOI to the steady-state period, as depicted in Figures 7(a) - (d). The evolution of the primary soot size is shown in Figure 8 to correspond to the net growth rates for the $15 \% \mathrm{O}_{2}$ and $12 \% \mathrm{O}_{2}$ cases, where a larger soot size is achieved in the former case due to having higher net growth rates. levels are comparable to one another during the early ignition stage ( $t \leq 2 \mathrm{~ms}$ ASOI).

344 However, the span of soot cloud for $12 \% \mathrm{O}_{2}$ case becomes longer than the $15 \% \mathrm{O}_{2}$ case at 345 later times ( $t \geq 3 \mathrm{~ms}$ ASOI). During steady-state period, the span of soot cloud for the $12 \%$ 
347 shows similar trend to the ones at low density, where the primary soot size is larger for the

$34815 \% \mathrm{O}_{2}$ (cf. Figure 8). In addition, increasing ambient density while keeping the ambient

349 oxygen constant leads to an increase in primary soot sizes. This is likely due to the higher net

350 growth rate achieved at higher ambient density, as depicted in Figure 7.

351

352

353

354

355

356

357

358

359

360

361

362

363

364

365

366

367

368

369

370

\subsubsection{Soot age distribution}

As the previous section has clearly demonstrated that the soot cloud span varies with different ambient conditions, it is expected that the longer span of the soot cloud would imply longer soot residence time in the spray flame. The use of the LST model allows the ability to analyse the residence time of soot in the spray flame by tracking the soot particles from the time of formation to the time of oxidation. The time duration of the soot particle from formation till oxidation is henceforth known as soot age [67]. It is important to note that the transient analysis of soot age is carried out after soot onset (ASO), where the soot onset time and onset location are tabulated in Table 3. The soot onset time is defined here as the earliest time after SOI when the total number of Lagrangian soot particles present in the domain are more than 100 particles. The soot onset location is taken as the axial distance from the nozzle to the point where the maximal SVF is present, at the soot onset time. From Table 3, it is shown that the soot onset time and location increase as oxygen level decreases at both ambient densities. Shorter soot onset time and a more upstream soot onset location are obtained when the ambient density increases. These results agree qualitatively with the experimental and numerical findings in [59] which uses $n$-dodecane as fuel.

Figure 9 shows the predicted temporal evolution of soot age distribution of the primary soot particles at the core of spray jet with different ambient oxygen levels and densities. From $1.0 \mathrm{~ms}$ to $3.0 \mathrm{~ms}$ ASO, the soot age distributions at different oxygen levels and ambient densities are similar to one another. A narrower distribution is obtained for the $15 \% \mathrm{O}_{2}$ case at high density as compared to the other cases at $4.0 \mathrm{~ms}$ ASO, which implies 
372 that the soot particles in the $15 \% \mathrm{O}_{2}$, high density case have a relatively shorter soot age than 373 the other cases.

It is mentioned in Section 3.2.2 that the cloud span for the $12 \% \mathrm{O}_{2}$, low density case is

375 shorter than the $15 \% \mathrm{O}_{2}$, low density case before reaching the steady-state period. Despite

376 having a shorter soot cloud span, the soot age distribution in Figure 9 shows no significant

377 difference between both oxygen level cases. This can be explained by the difference in the soot onset location in both cases. As mentioned earlier, the soot onset location for $15 \% \mathrm{O}_{2}$, low density case is more upstream than the $12 \% \mathrm{O}_{2}$ case (as shown in Table 3 ). As the soot

380 particles are formed nearer to the nozzle, the flow velocity experienced by the soot particles

381 is higher than the ones further downstream. Therefore, the time taken to travel along the spray flame is shorter. Meanwhile, the soot onset location for the $12 \% \mathrm{O}_{2}$ case is further downstream. The lower flow velocity experienced by the soot particles consequently lead to particles travelling more slowly through the spray flame. distribution at $4.0 \mathrm{~ms}$ ASO cf. Figure $9(\mathrm{~d})$ and a shorter soot cloud span than the $12 \% \mathrm{O}_{2}$ case at the steady-state period cf. Figure $8(\mathrm{~h})$. This observation can also be attributed to the soot onset location. The soot onset location for both oxygen levels are close to one another, as shown in Table 3. This implies that the flow velocities experience by the soot particles at

390 both oxygen levels are not significantly different. Therefore, the shorter soot cloud span in the $15 \% \mathrm{O}_{2}$ case would yield shorter soot age as what is predicted in Figure 9(d). The results

392 above also show that longer soot cloud span does not necessary equate to longer soot

393 residence time. The residence time of the soot particles in a spray flame is dependent on both

394 the soot cloud span and the soot onset location. 


\section{Conclusion}

396 The effect of ambient oxygen level and density on the prediction of soot volume fraction and soot size distribution are carried out using a Lagrangian soot tracking method on Sandia $n$ heptane spray cases. The simulated SVF for the $12 \% \mathrm{O}_{2}, 30.0 \mathrm{~kg} / \mathrm{m}^{3}$ density case is underpredicted by approximately $30 \%$ relative to the measured data. At low density, the predicted $\mathrm{SVF}$ at $15 \% \mathrm{O}_{2}$ is overpredicted by a factor of two. Despite these discrepancies, the qualitative trend of the measured SVF where the SVF increases with increasing oxygen level and ambient density is captured by the simulated SVF.

The peak primary soot size achieved in the core of the spray jet at an ambient density of $14.8 \mathrm{~kg} / \mathrm{m}^{3}$ and oxygen level of $15 \%$ and $12 \%$ are $14 \mathrm{~nm}$ and $10 \mathrm{~nm}$, respectively. Based on the primary soot size distribution in the core of the spray jet, an increase in ambient density from $14.8 \mathrm{~kg} / \mathrm{m}^{3}$ to $30 \mathrm{~kg} / \mathrm{m}^{3}$ is shown to increase the peak and mean primary soot size by a factor of 1.5. Furthermore, the peak and mean primary soot size decrease with decreasing oxygen levels from $15 \%$ to $12 \%$. Higher oxygen level and ambient density lead to higher net growth rate experience by the soot particles, resulting in larger primary soot sizes.

410 At low density, the soot cloud span is shorter for the $12 \% \mathrm{O}_{2}$ case as compared to the $15 \% \mathrm{O}_{2}$ case. On the contrary, the high density cases show comparable soot cloud span for both oxygen levels before steady-state period. With the introduction of soot age, the present study shows that longer span of the soot cloud does not equate to longer soot residence time in the spray flame.

Despite having different soot cloud span, the soot age distributions at different oxygen levels and ambient densities are similar to one another from $1.0 \mathrm{~ms}$ to $4.0 \mathrm{~ms}$ after soot onset time. The reason for this is likely due to the soot onset location. Soot particles that form upstream of the spray will experience higher flow velocity, thus leading to a shorter soot age when the span of the soot cloud is short. 


\section{References}

421 [1] Chen L, Liang Z, Zhang X, Shuai S. Characterizing particulate matter emissions from GDI and PFI vehicles under transient and cold start conditions. Fuel 2017;189:13140.

[2] Liu H, Ma X, Li B, Chen L, Wang Z, Wang J. Combustion and emission characteristics of a direct injection diesel engine fueled with biodiesel and PODE/biodiesel fuel blends. Fuel 2017;209:62-8.

[3] Kazemimanesh M, Moallemi A, Olfert JS, Kostiuk LW. Probe sampling to map and characterize nanoparticles along the axis of a laminar methane jet diffusion flame. Proc Combust Inst 2017;36:881-8.

[4] Bockhorn H. Combustion Generated Fine Carbonaceous Particles: Proceedings of an International Workshop Held in Villa Orlandi, Anacapri, May 13-16, 2007. KIT Scientific Publishing; 2009.

[5] Schwartz J. Air pollution and daily mortality: a review and meta analysis. Environ Res 1994;64:36-52.

[6] European Parliament, Council of the European Union. REGULATION (EC) No 715/2007 OF THE EUROPEAN PARLIAMENT AND OF THE COUNCIL of 20 June 2007 on type approval of motor vehicles with respect to emissions from light passenger and commercial vehicles (Euro 5 and Euro 6) and on access to vehicle repair and mai. Off J Eur Union 2007;L171:1-16. doi:OJEU 29.6.2007 L171.

440 [7] Le Coq L. Élimination Des Particules. Tech l'Ingénieur 2006;33:20.

441 [8] Kook S, Pickett LM. Soot volume fraction and morphology of conventional and surrogate jet fuel sprays at 1000-K and 6.7-MPa ambient conditions. Proc Combust Inst 2011;33:2911-8.

444 [9] Yamaguchi T, Kondo K, Nishigai H, Takano S, Aizawa T. Direct Sampling, TEM 
analysis and optical measurement of soot particles at different axial locations in a transient spray flame. SAE Int J Fuels Lubr 2011;5:316-28.

[10] Kondo K, Yamaguchi T, Nishigai H, Takano S, Aizawa T. High-Resolution Transmission Electron Microscopy of soot directly sampled at different axial locations in diesel spray Flame, No. 2011-24-0068, SAE Technical Paper, 2011.

[11] Aizawa T, Nishigai H, Kondo K, Yamaguchi T, Nerva JG, Genzale C, Kook S, Pickett L. Transmission electron microscopy of soot particles directly sampled in diesel spray flame - a comparison between US\#2 and biodiesel soot. SAE Int J Fuels Lubr 2012;5:665-73. doi:10.4271/2012-01-0695.

[12] Aizawa T, Takahata N, Okabe K, Mizutani Y. Effect of fuel aromatics on in-flame diesel soot nanostructure via HRTEM. No. 2015-01-1829. SAE Technical Paper; 2015.

[13] Kuribayashi M, Ishizuka Y, Aizawa T. Sizing of soot particles in diesel spray flame-a qualitative comparison between TEM analysis and LII/scattering laser measurements. SAE Int J Fuels Lubr 2013; 6(3):641-50.

[14] Kuribayashi M, Mizutani Y, Ishizuka Y, Taki N, Aizawa T. Effects of ambient oxygen concentration on soot processes in diesel spray flame-A qualitative comparison between TEM analysis and LII/Scattering laser measurements. SAE Int J Fuels Lubr 2014;7:693-703.

[15] Kook S, Zhang R, Szeto K, Pickett LM, Aizawa T. In-flame soot sampling and particle analysis in a diesel engine. SAE Int J Fuels Lubr 2013;6:80-97. doi:10.4271/2013-010912.

[16] Zhang R, Kook S. Structural evolution of soot particles during diesel combustion in a single-cylinder light-duty engine. Combust Flame 2015;162:2720-8. of the morphology and nanostructure of the soot particles produced within transient 
diesel reacting jet flame by using thermophoretic sampling technique. Energy \& Fuels

471

472

473

474

475

476

477

478

479

480

481

482

483

484

485

486

487

488

489

490

491

492

493

494 2019;33:9124-37.

[18] Nerva JG, Yamaguchi T, Iguma H, Nishigai H, Kondo K, Takano S, Aizawa T, Genzale CL, Pickett LM. Transmission electron microscopy of soot particles sampled directly from a biodiesel spray flame. SAE Int J Fuels Lubr 2011;5:2011-01-2046. doi:10.4271/2011-01-2046.

[19] Sakai M, Iguma H, Kondo K, Aizawa T. Nanostructure analysis of primary soot particles directly sampled in diesel spray flame via HRTEM. No. 2012-01-1722. SAE Technical Paper; 2012.

[20] Jiang H, Li T, Wang Y, He P, Wang B. The evolution of soot morphology and nanostructure along axial direction in diesel spray jet flames. Combust Flame 2019;199:204-12.

[21] Frenklach M. Method of moments with interpolative closure. Chem Eng Sci 2002;57:2229-39.

[22] Mueller ME, Blanquart G, Pitsch H. A joint volume-surface model of soot aggregation with the method of moments. Proc Combust Inst 2009;32:785-92.

[23] Ito T, Hosaka T, Ueda M, Senda J, Fujimoto H. Detailed kinetic modeling and laser diagnostics of soot formation process in diesel jet flame. SAE Transactions. 2004;1:602-13.

[24] Naik CV, Puduppakkam KV, Meeks E. Simulation of soot volume fraction and size in high-pressure lifted flames using detailed reaction mechanisms. ASME Turbo Expo 2014 Turbine Tech Conf Expo 2014:V04BT04A025.

[25] Gelbard F, Seinfeld JH. Simulation of multicomponent aerosol dynamics. J Colloid Interface Sci 1980;78:485-501.

[26] Gelbard F, Tambour Y, Seinfeld JH. Sectional representations for simulating aerosol 
dynamics. J Colloid Interface Sci 1980;76:541-56.

496

497

498

499

500

501

502

503

504

505

506

507

508

509

510

511

512

513

514

515

516

517

518

519

[27] Pope CJ, Howard JB. Simultaneous particle and molecule modeling (SPAMM): An approach for combining sectional aerosol equations and elementary gas-phase reactions. Aerosol Sci Technol 1997;27:73-94.

[28] Aubagnac-Karkar D, Michel J-B, Colin O, Noël L, Darabiha N. A Sectional Soot Model for RANS Simulation of Diesel Engines. SAE Technical Paper; 2014.

[29] Aubagnac-Karkar D, Michel J-B, Colin O, Vervisch-Kljakic PE, Darabiha N. Sectional soot model coupled to tabulated chemistry for Diesel RANS simulations. Combust Flame 2015;162:3081-99.

[30] Gallen L, Felden A, Riber E, Cuenot B. Lagrangian tracking of soot particles in LES of gas turbines. Proceedings of the Combustion Institute. 2019 Jan 1;37(4):5429-36.

[31] Dellinger N, Bertier N, Dupoirieux F, Legros G. Hybrid Eulerian-Lagrangian method for soot modelling applied to ethylene-air premixed flames. Energy. 2020 Mar $1 ; 194: 116858$.

[32] Ong JC, Pang KM, Walther JH, Ho J-H, Ng HK. Evaluation of a Lagrangian soot tracking method for the prediction of primary soot particle size under engine-like conditions. J Aerosol Sci 2018;115:70-95.

[33] Weller HG, Tabor G, Jasak H, Fureby C. A tensorial approach to computational continuum mechanics using object-oriented techniques. Comput Phys 1998;12:62031.

[34] ECN. Engine Combustion Network 2020. www.sandia.gov/ecn/.

[35] Reitz RD, Diwakar R. Effect of drop breakup on fuel sprays. SAE Transactions. $1986 ; 1: 218-27$.

[36] Launder BE, Spalding DB. The numerical computation of turbulent flows. Comput Methods Appl Mech Eng 1974;3:269-89. doi:https://doi.org/10.1016/0045- 
521

522

[37] Novella R, García A, Pastor JM, Domenech V. The role of detailed chemical kinetics on CFD diesel spray ignition and combustion modelling. Math Comput Model 2011;54:1706-19.

[38] Pang KM, Jangi M, Bai X-S, Schramm J. Investigation of chemical kinetics on soot formation event of n-heptane spray combustion. No. 2014-01-1254. SAE Technical Paper; 2014.

[39] Pang KM, Jangi M, Bai X-S, Schramm J. Evaluation and optimisation of phenomenological multi-step soot model for spray combustion under diesel enginelike operating conditions. Combust Theory Model 2015;19:279-308.

[40] Varna A, Wehrfritz A, Hawkes ER, Cleary MJ, Lucchini T, D’Errico G, Kook S, Chan QN. Application of a multiple mapping conditioning mixing model to ECN Spray A. Proceedings of the Combustion Institute. 2019 Jan 1;37(3):3263-70.

[41] Skeen S, Manin J, Pickett L, Dalen K, Ivarsson A. Quantitative spatially resolved measurements of total radiation in high-pressure spray flames. No. 2014-01-1252. SAE Technical Paper; 2014.

[42] Jangi M, D'Errico G, Bai X-S, Lucchini T. Numerical simulation of the ECN Spray A using multidimensional chemistry coordinate mapping: n-dodecane diesel combustion. No. 2012-01-1660. SAE Technical Paper; 2012.

[43] Ranz WE, Marshall WR. Evaporation from drops. Chem Eng Prog 1952;48:141446.

[44] Frossling N. Evaporation, heat transfer, and velocity distribution in two-dimensional and rotationally symmetrical laminar boundary-layer flow. DTIC Document; 1956.

[45] Pang KM, Ng HK, Gan S. Development of an integrated reduced fuel oxidation and soot precursor formation mechanism for CFD simulations of diesel combustion. Fuel 2011;90:2902-14. 
545 [46] Kitanidis PK. Particle-tracking equations for the solution of the advection-dispersion equation with variable coefficients. Water Resour Res 1994;30:3225-7.

[47] Zhang Z, Chen Q. Comparison of the Eulerian and Lagrangian methods for predicting particle transport in enclosed spaces. Atmos Environ 2007;41:5236-48.

[48] Bolla M, Wright YM, Boulouchos K, Borghesi G, Mastorakos E. Soot formation modeling of $\mathrm{n}$-heptane sprays under diesel engine conditions using the conditional moment closure approach. Combustion Science and Technology. 2013 May 4;185(5):766-93.

[49] Haynes BS, Wagner HG. The surface growth phenomenon in soot formation. Zeitschrift für Physikalische Chemie. 1982 Feb 1;133(2):201-13.

[50] Brookes SJ, Moss JB. Predictions of soot and thermal radiation properties in confined turbulent jet diffusion flames. Combust Flame 1999;116:486-503.

[51] Ong, JC, Development of Lagrangian soot tracking method for the study of soot morphology in diesel spray combustion. PhD Thesis. University of Nottingham, 2017.

[52] Leung KM, Lindstedt RP, Jones WP. A simplified reaction mechanism for soot formation in nonpremixed flames. Combust Flame 1991;87:289-305.

[53] Vishwanathan G, Reitz RD. Development of a practical soot modeling approach and its application to low-temperature diesel combustion. Combust Sci Technol 2010;182:1050-82.

[54] Katta VR, Blevins LG, Roquemore WM. Dynamics of an inverse diffusion flame and its role in polycyclic-aromatic-hydrocarbon and soot formation. Combust Flame 2005;142:33-5

[55] Pei Y, Som S, Pomraning E, Senecal PK, Skeen SA, Manin J, Pickett LM. Large eddy simulation of a reacting spray flame with multiple realizations under compression ignition engine conditions. Combustion and Flame. 2015 Dec 1;162(12):4442-55. 
[56] Fernandez SF, Paul C, Sircar A, Imren A, Haworth DC, Roy S, Modest MF. Soot and spectral radiation modeling for high-pressure turbulent spray flames. Combustion and Flame. 2018 Apr 1;190:402-15.

[57] Chishty MA, Bolla M, Hawkes ER, Pei Y, Kook S. Soot formation modelling for ndodecane sprays using the transported PDF model. Combustion and Flame. 2018 Jun 1;192:101-19.

[58] Idicheria CA, Pickett LM. Soot formation in diesel combustion under high-EGR conditions. SAE Transactions. 2005;1:1559-74.

[59] Cenker E. Imaging measurements of soot particle size and soot volume fraction with laser-induced incandescence at Diesel engine conditions. Ph.D. Thesis., Ecole Centrale Paris, 2014.

[60] Pandurangi SS, Bolla M, Wright YM, Boulouchos K, Skeen SA, Manin J, Pickett LM. Onset and Progression of Soot in high-pressure n-Dodecane Sprays under DieselEngine Conditions. Int J Engine Re. 2017;18(5-6):436-52.

[61] Kook S, Zhang R, Chan QN, Aizawa T, Kondo K, Pickett LM, Cenker E, Bruneaux G, Andersson O, Pagels J, Nordin EZ. Automated detection of primary particles from transmission electron microscope (TEM) images of soot aggregates in diesel engine environments. SAE Int J Engines 2016;9:279-96.

[62] Pickett LM, Siebers DL. Soot in diesel fuel jets: effects of ambient temperature, ambient density, and injection pressure. Combust Flame 2004;138:114-35.

[63] Oh KC, Shin HD. The effect of oxygen and carbon dioxide concentration on soot formation in non-premixed flames. Fuel 2006;85:615-24.

[64] Vargas AM, Gülder ÖL. Pressure dependence of primary soot particle size determined using thermophoretic sampling in laminar methane-air diffusion flames. Proc Combust Inst 2017;36:975-84. 
595 [65] Amin HMF, Roberts WL. An experimental apparatus to measure soot morphology at 596 high pressures using multi-angle light scattering. Meas Sci Technol 2019;30:75902.

597 [66] Amin HMF, Roberts WL. Investigating soot parameters in an ethane/air counterflow 598 diffusion flame at elevated pressures. Combust Sci Technol 2020:1-16.

599 [67] Singh J, Balthasar M, Kraft M, Wagner W. Stochastic modeling of soot particle size $600 \quad$ and age distributions in laminar premixed flames. Proc Combust Inst 2005;30:1457601 65.

602 


\section{List of Figures}
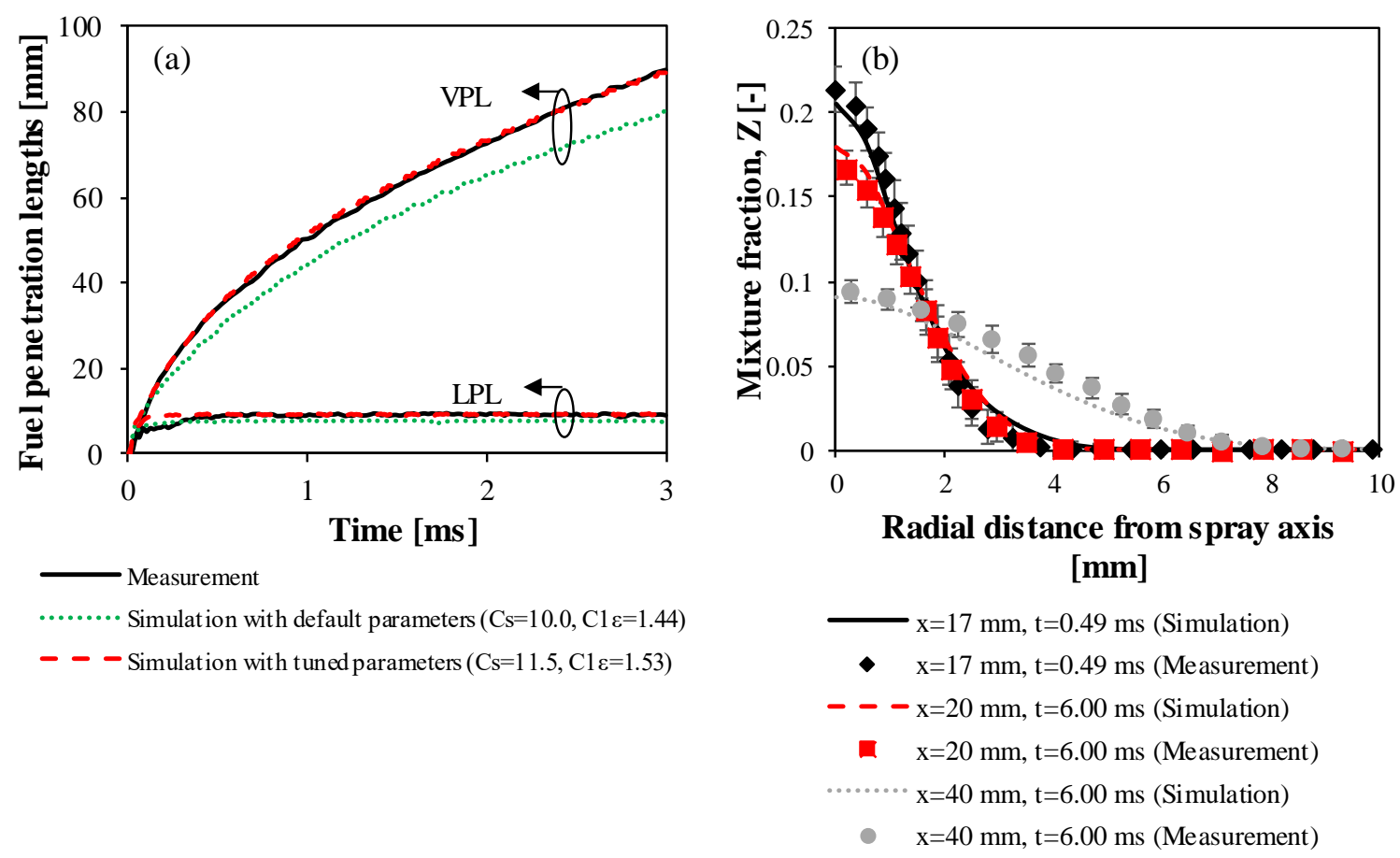

Figure 1: (a) Comparison of liquid and vapour penetration length for the non-reacting $n$ heptane spray case. (b) Comparison of simulated and experimental radial mixture fraction of the non-reacting $n$-heptane spray case at different axial locations and time after injection. 

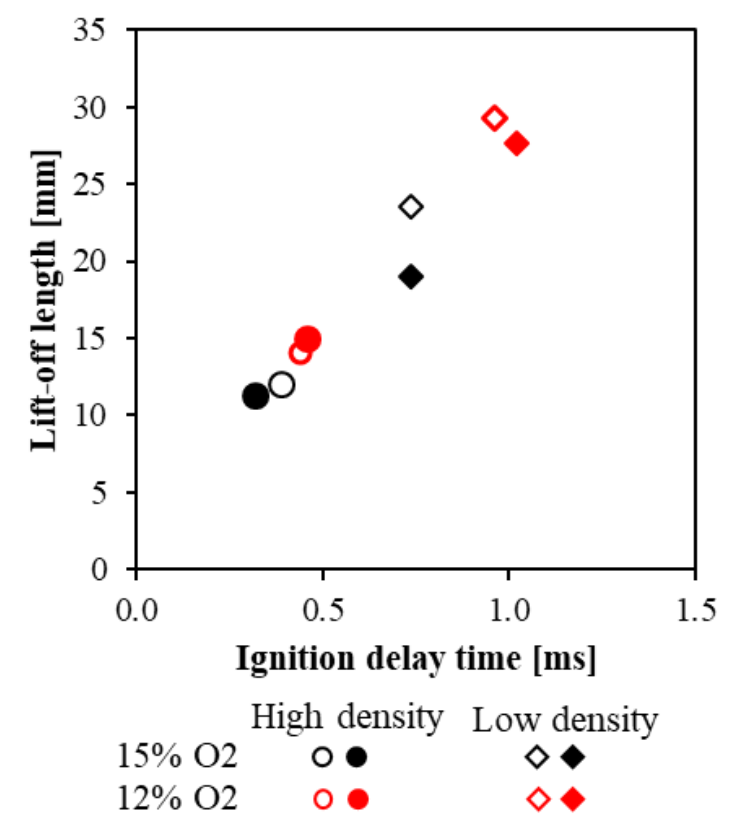

Figure 2: Comparison of simulated ignition delay time (IDT) and lift-off length (LOL) for the reacting $n$-heptane spray cases with experimental results at different ambient oxygen levels and ambient densities. [Hollow symbols represent measured data; Filled symbols represent simulation data] 


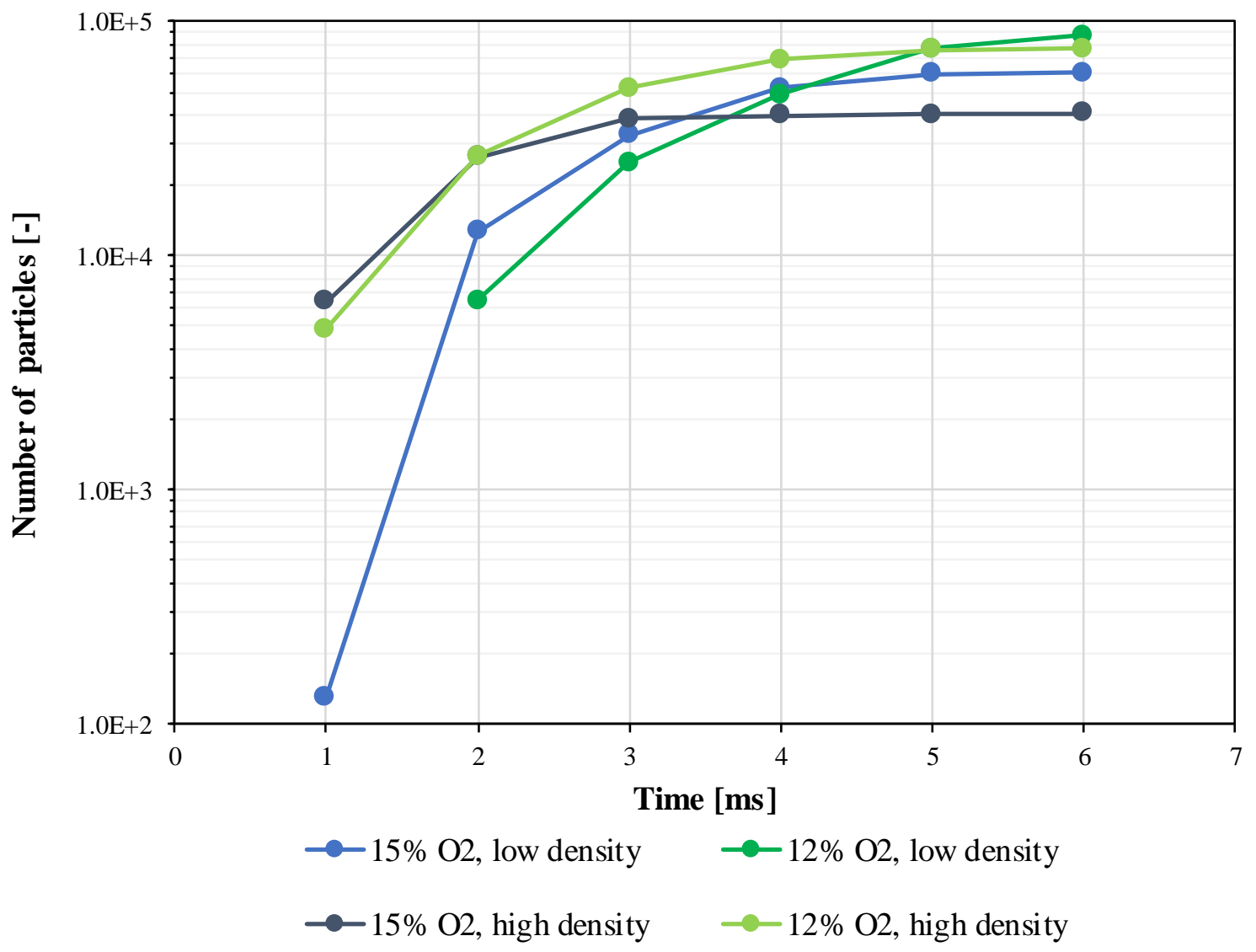

Figure 3: Temporal evolution of the number of computational particles for soot under different ambient densities and oxygen levels. 


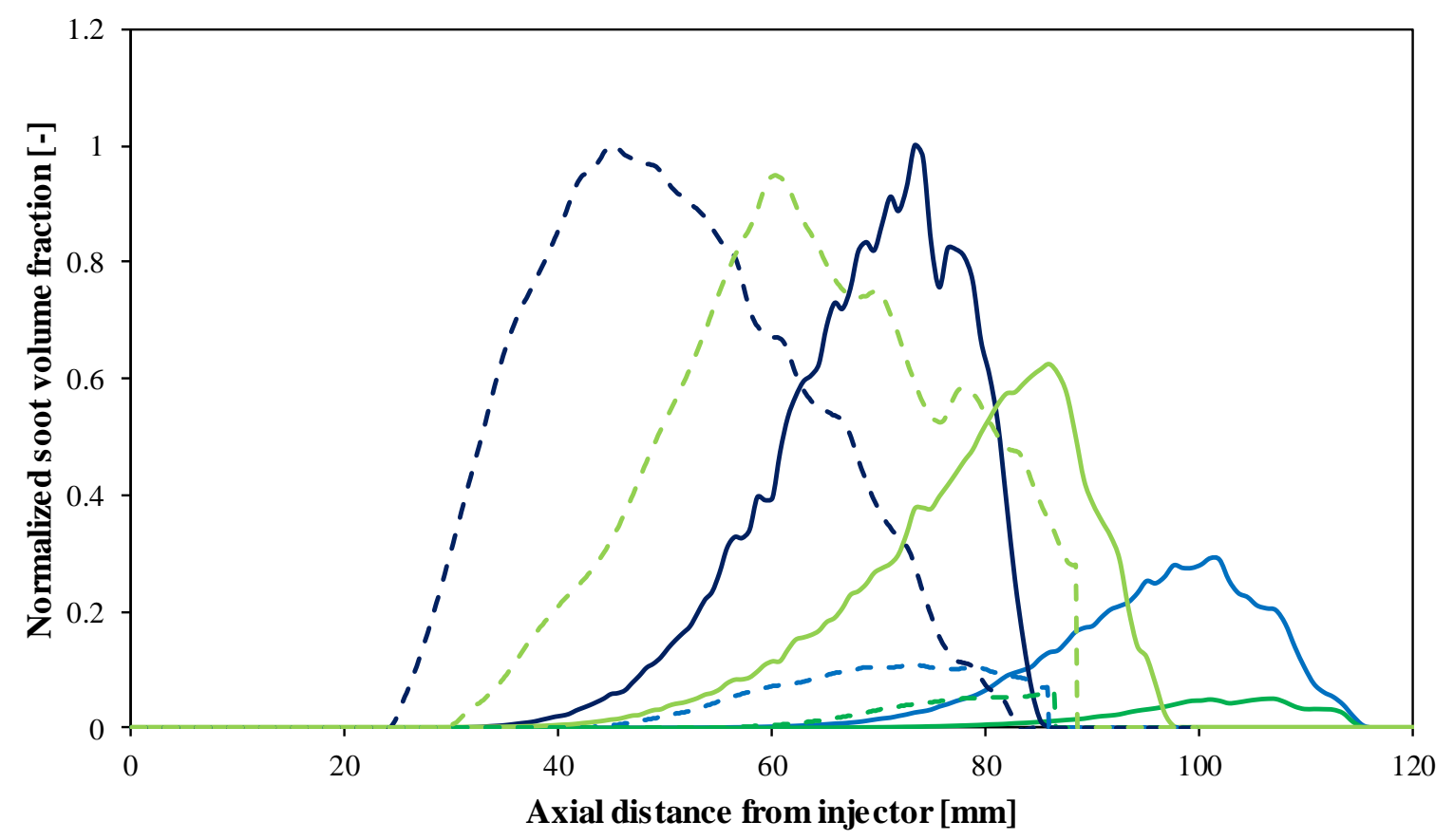

- Simulation ( $15 \%$ O2, low density)

- Simulation (12\% O2, low density)

- Simulation (15\% O2, high density)

- Simulation (12\% O2, high density)

- - - Measurement (15\% O2, low density)

- - - Measurement (12\% O2, low density)

- - - Measurement (15\% O2, high density)

- - - Measurement (12\% O2, high density)

Figure 4: Normalized SVF as a function of the axial distance from injector for $15 \%$ and $12 \%$ oxygen levels at ambient density of $14.8 \mathrm{~kg} / \mathrm{m}^{3}$ (low density) and $30.0 \mathrm{~kg} / \mathrm{m}^{3}$ (high density). 


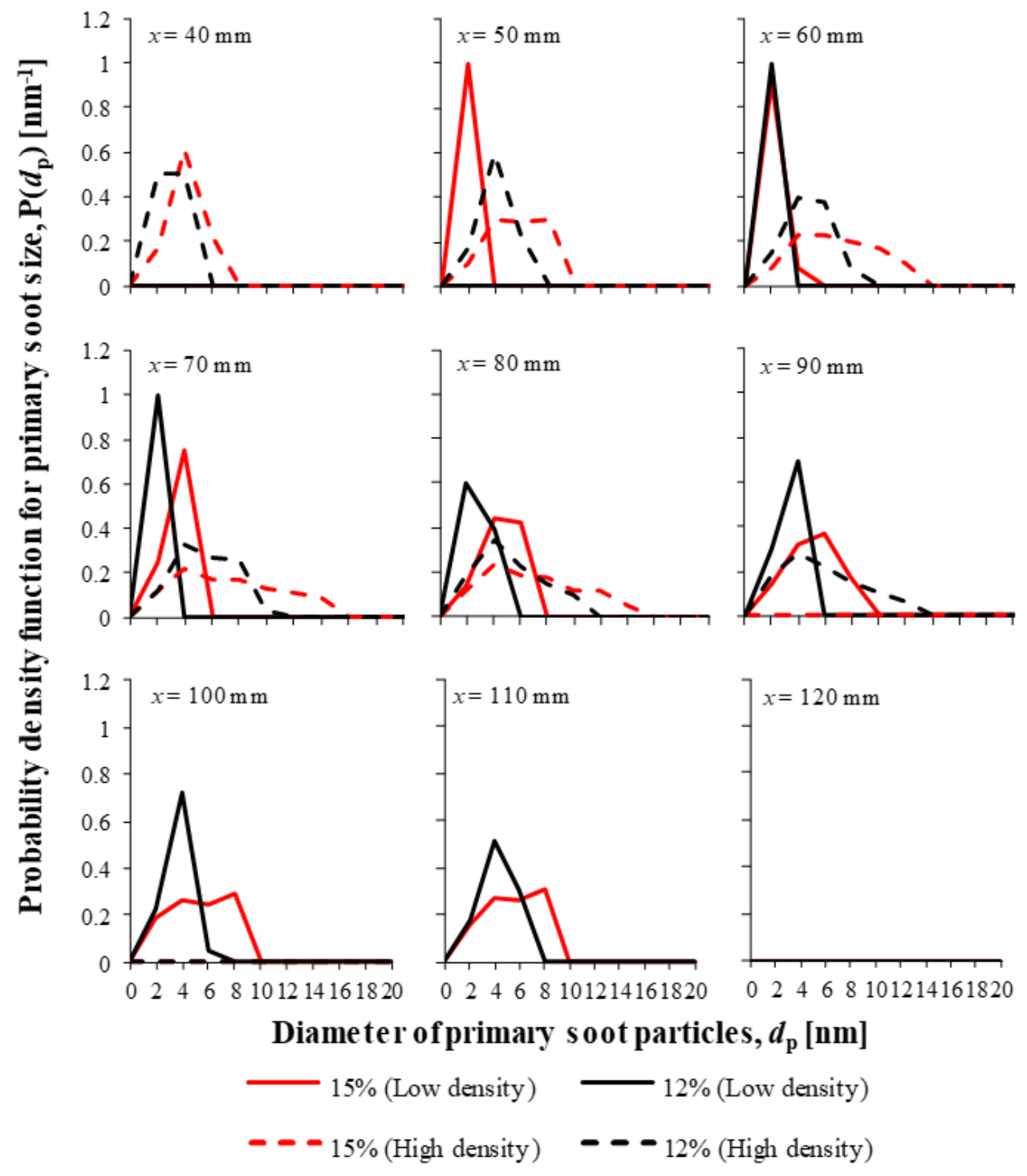

Figure 5: Probability density function (PDF) of primary soot size predicted along various axial locations from injector location for different ambient oxygen level and density cases. 


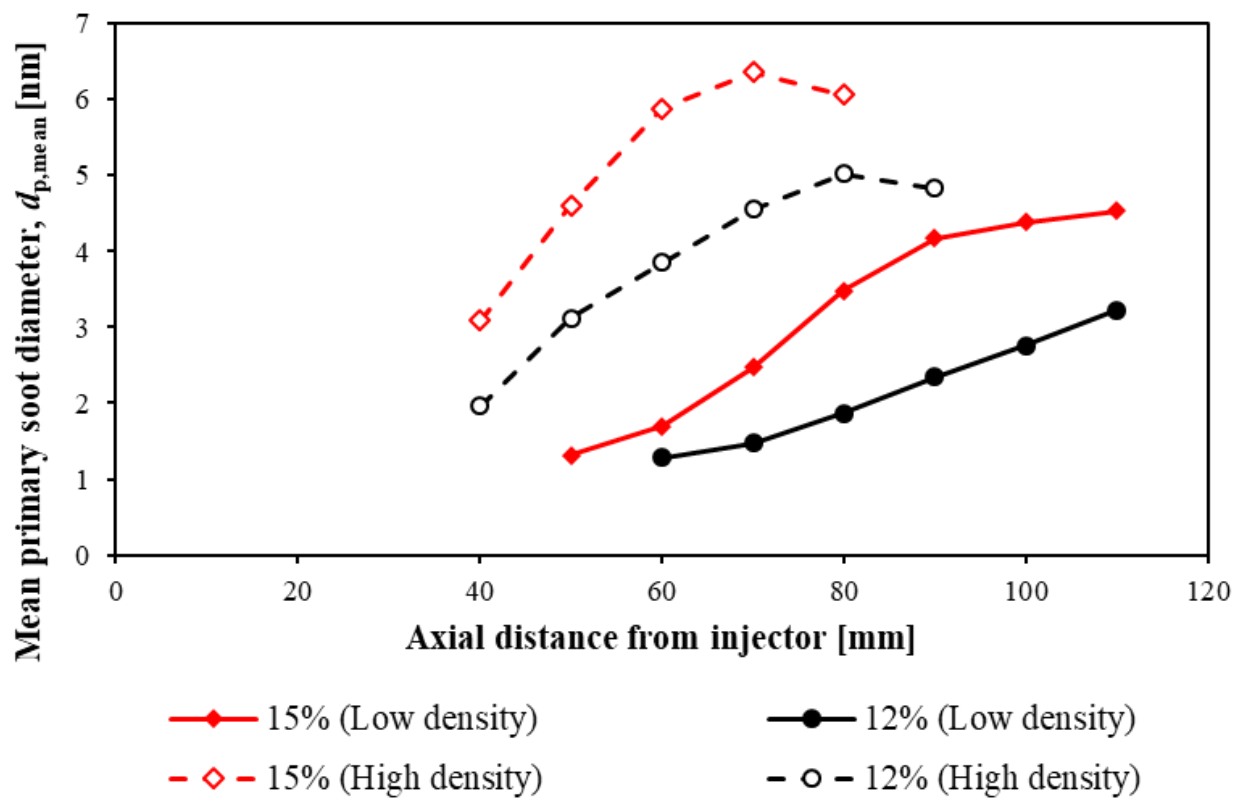

Figure 6: Mean primary soot size as a function of axial distance from injector for different ambient oxygen level and density cases. The filled symbols refer to low density cases; hollow symbols refer to high density cases. 


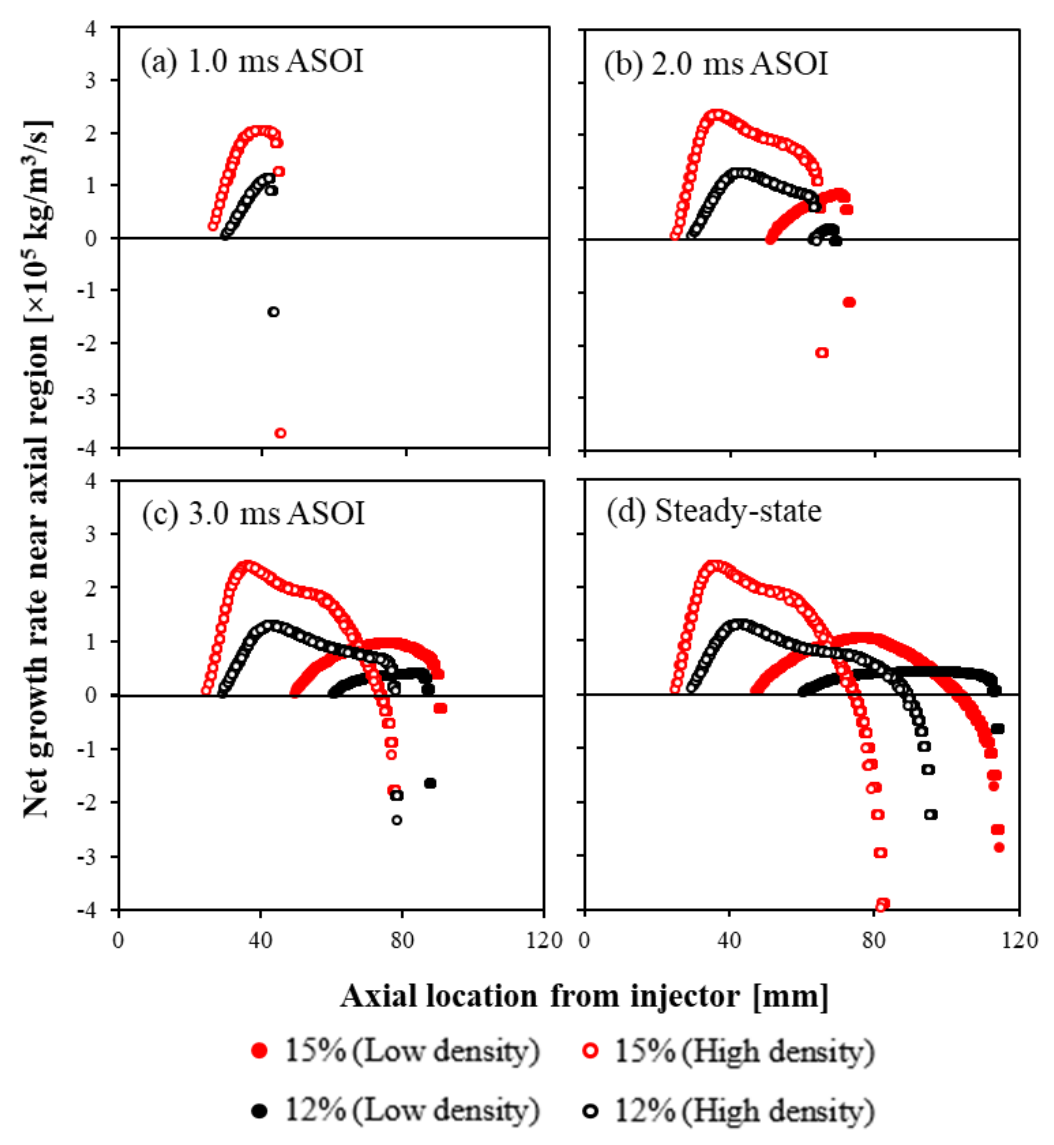

Figure 7: Temporal evolution of the net growth rates at core of spray jet for different ambient oxygen level and density cases at different timings. The filled symbols refer to low density cases; hollow symbols refer to high density cases. 


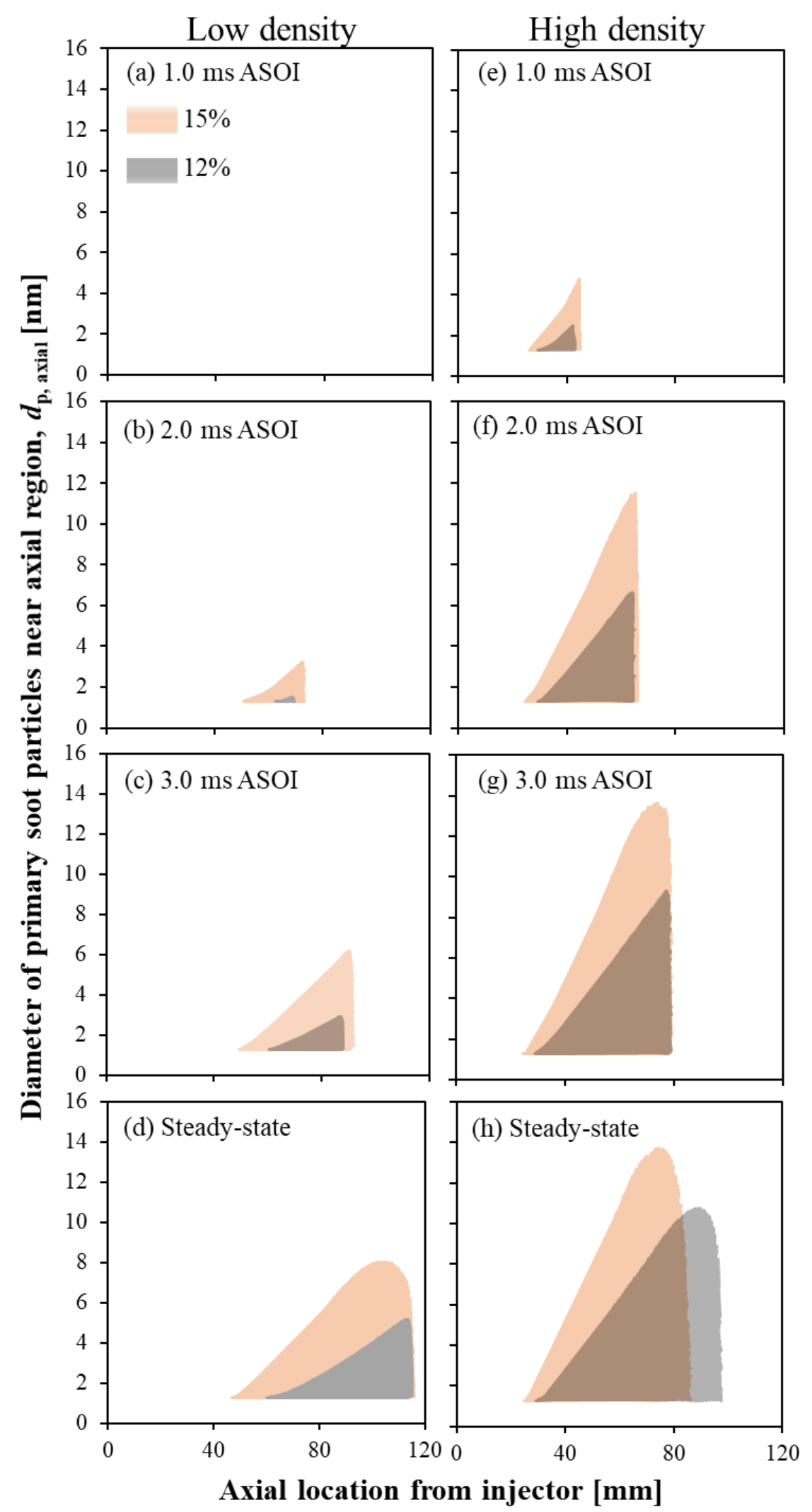

Figure 8: Primary soot size distribution at the core of the spray jet for different ambient oxygen level and density cases. (a) - (d) refer to low density cases and (e) - (f) refer to high density cases. 


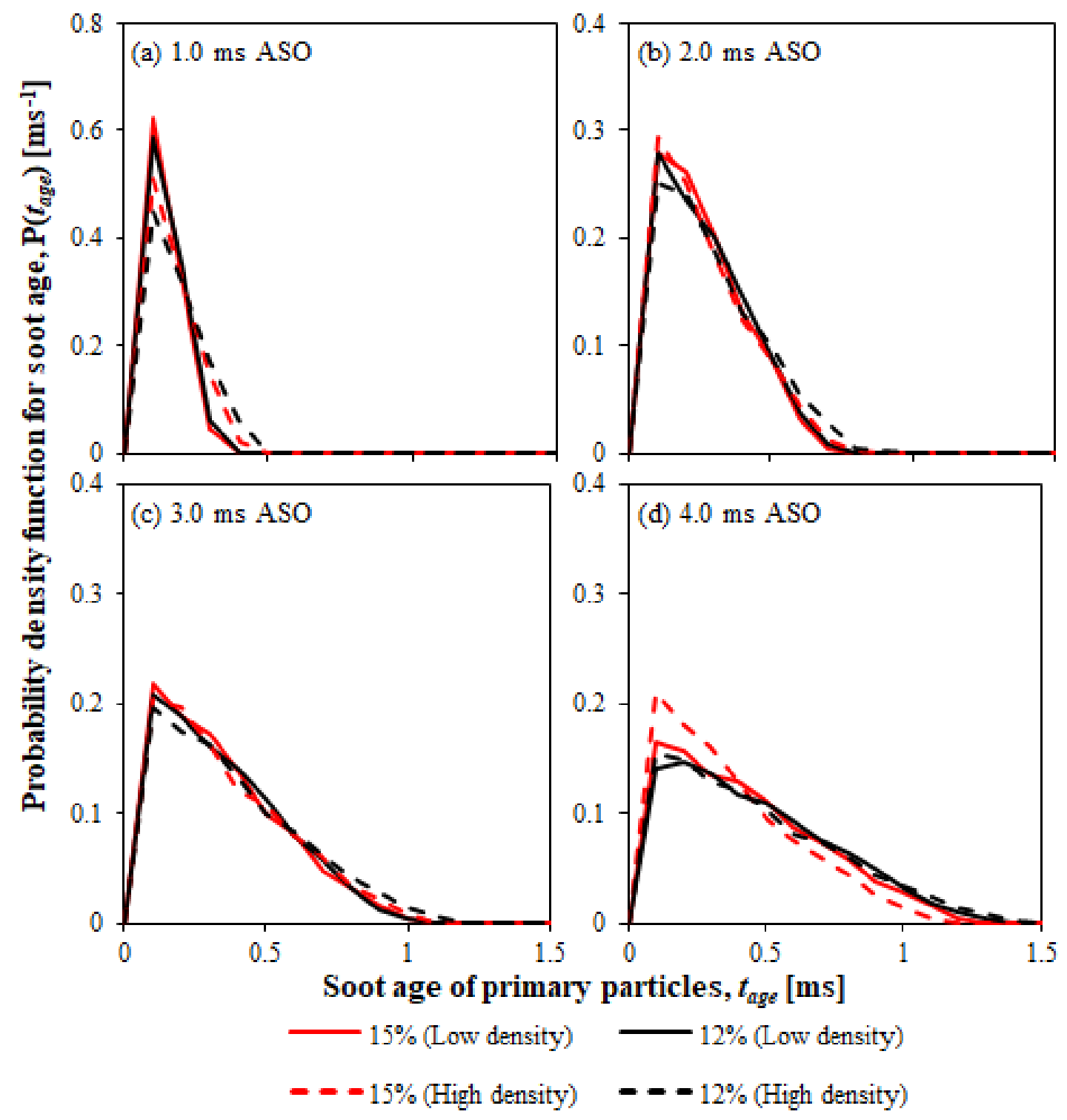

Figure 9: Soot age distribution of soot particles at the core of spray jet for different ambient oxygens and densities at different timing ASO. Solid lines refer to low density cases; dashed lines refer to high density cases. 


\section{List of Tables}

Table 1: Experimental conditions for Sandia $n$-heptane test cases. Data taken from Ref. [34].

\begin{tabular}{llllllll}
\hline $\begin{array}{l}\text { Spray } \\
\text { configuration }\end{array}$ & $\begin{array}{l}\boldsymbol{T}_{\boldsymbol{a m}} \\
{[\mathbf{K}]}\end{array}$ & $\begin{array}{l}\boldsymbol{\rho}_{\boldsymbol{a m}} \\
{\left[\mathrm{kg} / \mathbf{m}^{3}\right]}\end{array}$ & $\mathbf{O}_{\mathbf{2}} \%$ & $\begin{array}{l}\text { Injection } \\
\text { duration } \\
{[\mathbf{m s}]}\end{array}$ & $\begin{array}{l}\text { Nozzle orifice } \\
\text { diameter } \\
{[\mathbf{m m}]}\end{array}$ & $\begin{array}{l}\text { Injection } \\
\text { pressure } \\
\text { drop } \\
{[\mathrm{MPa}]}\end{array}$ & $\begin{array}{l}\text { Total fuel } \\
\text { mass [mg] }\end{array}$ \\
\hline Non-reacting & 1000 & 14.8 & 0 & 6.8 & 0.1 & 150 & 17.8 \\
Reacting & 1000 & 14.8 & 15 & 6.8 & 0.1 & 150 & 17.8 \\
& & & 12 & 6.8 & 0.1 & 150 & 17.8 \\
& 1000 & 30.0 & 15 & 6.8 & 0.1 & 150 & 18.0 \\
& & & 12 & 6.8 & 0.1 & 150 & 17.8 \\
\hline
\end{tabular}

$\overline{T_{a m}}:$ Ambient temperature $; \rho_{\text {am }}:$ Ambient density $; \mathrm{O}_{2} \%:$ Ambient oxygen concentration (in mole fraction)

Table 2: The soot model constants. Data taken from Ref. [50,52]

\begin{tabular}{cll}
\hline $\begin{array}{l}\text { Soot } \\
\text { Model } \\
\text { Constants }\end{array}$ & Descriptions & Value [Unit] \\
\hline$C_{s g}$ & Surface growth rate scaling factor & $11,700\left[\mathrm{~kg} \mathrm{~m} \mathrm{kmol}^{-1} \mathrm{~s}^{-1}\right]$ \\
$C_{O H}$ & Model constant for soot oxidation due to $\mathrm{OH}$ & $105.81\left[\mathrm{~kg} \mathrm{~m} \mathrm{kmol}^{-1} \mathrm{~K}^{-0.5} \mathrm{~s}^{-1}\right]$ \\
$C_{O_{2}}$ & Model constant for soot oxidation due to $\mathrm{O}_{2}$ & $8903.51\left[\mathrm{~kg} \mathrm{~m} \mathrm{kmol}^{-1} \mathrm{~K}^{-0.5} \mathrm{~s}^{-1}\right]$ \\
$T_{s g}$ & Activation temperature of surface growth & $12,100[\mathrm{~K}]$ \\
$T_{O_{2}}$ & Activation temperature of soot oxidation due & $19,778[\mathrm{~K}]$ \\
& to O O & $0.13[-]$ \\
\hline
\end{tabular}

Table 3: Soot onset time and onset location for different ambient oxygen level and density $n$ heptane spray cases.

\begin{tabular}{lccc}
\hline $\begin{array}{l}\text { Ambient density } \\
{\left[\mathbf{k g} / \mathbf{m}^{\mathbf{3}}\right]}\end{array}$ & $\begin{array}{l}\text { Ambient oxygen } \\
{[\%]}\end{array}$ & $\begin{array}{l}\text { Soot onset time } \\
{[\mathbf{m s}]}\end{array}$ & $\begin{array}{l}\text { Soot onset location } \\
{[\mathbf{m m}]}\end{array}$ \\
\hline 14.8 & 15 & 0.94 & 48 \\
& 12 & 1.38 & 58 \\
30.0 & 15 & 0.41 & 27 \\
& 12 & 0.57 & 30 \\
\hline
\end{tabular}

